\title{
Occurrence of arsenic and related microbial signature of hydrothermal systems in Western Turkey
}

\author{
C.-Y. Chen \& J.P. Maity \\ Department of Earth and Environmental Sciences, National Chung Cheng University, Tainan, Taiwan \\ J. Bundschuh \& P. Bhattacharya \\ KTH-International Groundwater Arsenic Research Group, Department of Land and Water Resources \\ Engineering, Royal Institute of Technology (KTH), Stockholm, Sweden
}

\author{
A. Baba \\ Izmir Institute of Technology, Engineering Faculty, Department of Civil Engineering, Turkey \\ O. Gunduz \\ Dokuz Eylul University, Department of Environmental Engineering, Izmir, Turkey
}

\begin{abstract}
The naturally occurring aqueous Arsenic (As) and other toxic elements are found around the world. The present study concentrates on arsenic concentrations, speciation and related microbial diversity in a hydrothermal system in Western Turkey. The surface temperatures of hot springs reach up to $90^{\circ} \mathrm{C}$ and deep well (reservoir) temperatures vary in the range of 40 to $230^{\circ} \mathrm{C}$. The elements such as $\mathrm{As}, \mathrm{B}, \mathrm{Br}, \mathrm{Ba}, \mathrm{Cr}, \mathrm{Fe}, \mathrm{Mn}, \mathrm{V}$ and $\mathrm{Zn}$ are found in high concentration in hydrothermal waters. Hydrogeochemically, Seferihisar hot spring exhibited a $\mathrm{Na}-\mathrm{Cl}$ water type. On the other hand, Karahayıt, Pamukkale, Emirfakı, Alaşehir and Sart exhibit a $\mathrm{Ca}-\mathrm{HCO}_{3}$ water type and Çitgöl exhibited a $\mathrm{Na}-\mathrm{HCO}_{3}-\mathrm{SO}_{4}$ water type. The arsenic (As) concentrations in geothermal waters of Western Anatolia have been detected to range from $0.03 \mathrm{mg} / \mathrm{L}$ to $1.5 \mathrm{mg} / \mathrm{L}$, including Buharkent (İnalt1) $(1.50 \pm 0.005 \mathrm{mg} / \mathrm{L})$, Kızıldere $(1.13 \pm 0.005 \mathrm{mg} / \mathrm{L})$, Eynal $(0.71 \pm 0.005 \mathrm{mg} / \mathrm{L})$ and Sarayköy $(0.06 \pm 0.004 \mathrm{mg} / \mathrm{L})$. Arsenic (III) is the dominant species in geothermal water of Western Anatolia. The 16S rRNA gene sequences of bacterial diversity show that the thermophilic, sulfur/thiosulfateoxidizing bacterium (Thiobacter subterraneus) is present in Kula geothermal water and mesophilic sulfur- and thiosulfate-oxidizing Sulfurovum lithotrophicum bacterium occurs in Sarayköy geothermal spring. Also, Bacillus fumarioli, (a thermophilic, aerobic endospore forming bacterium growing on $\left(\mathrm{NH}_{4}\right)_{2} \mathrm{SO}_{4}, \mathrm{MgSO}_{4}$ and $\mathrm{MnSO}_{4}$ at $\left.50-55^{\circ} \mathrm{C}\right)$, Schlegelella thermodepolymerans and Methylocaldum szegediense are rich in geothermal water.
\end{abstract}

\section{INTRODUCTION}

The metal-rich geothermal systems have been found throughout the world. In several geographical locations (Turkey, India, Bangladesh, and Taiwan), As occurs naturally in subsurface strata within volcanic and sedimentary formations.

The contamination of waters with heavy metals such as hydrothermally derived As is the most severe environmental impact in Western Turkey (Baba and Armannsson, 2006). The dominant As species in the environmental setting is controlled by many parameters, e.g. $\mathrm{pH}$, Eh, temperature dependent microbial activity, precipitation, adsorption reactions. These are generally driven by the presence of organic matter and inorganic electron donors (sulfide).

The aims of the present study were to establish the biogeochemical behavior and characteristics of arsenic in the hydrothermal waters of Western Turkey.

\section{MATERIALS AND METHODS}

\subsection{Study area and sampling}

The sampling points are shown in Figure 1. Water samples were filtered using $0.45 \mu \mathrm{m}$ syringe filters in the field, collected in dark sterilized Vacutainer and stored at $4^{\circ} \mathrm{C}$ until analysis. 


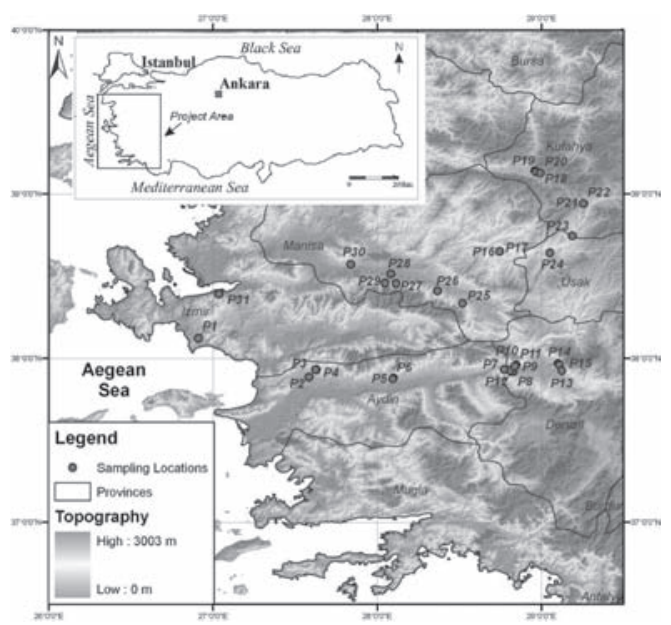

Figure 1. Location of the sampling points.

\subsection{Physico-chemical analysis}

Electrical Conductivity (EC), Total Dissolved Solids (TDS), Dissolved Oxygen (DO), temperature, salinity, $\mathrm{pH}$, Eh were measured with portable multi parameter probe (Hach-Lange HQ40d). The major ions and trace elements were measured using Ion Chromatograph (IC) (Dionex, CA) and ICP-MS (Hewlett-Packard 4500), respectively.

\subsection{Microbial analysis}

A Genomic DNA extraction kit (Viogene, Taipei, Taiwan) was used to isolate the genomic DNA from hot spring water. DGGE was performed on a Dcode universal mutation detection system (Bio-Rad, Hercules, CA), 16S rDNA fragments were loaded onto an $8 \%$ polyacrylamide gel. The sequence fractures $(\sim 1500 \mathrm{bp})$ were doing blast in GeneBank of NCBI, to compare the difference for nucleotide sequences.

\section{RESULTS AND DISCUSSION}

\subsection{Hydrochemistry and trace element in fluids}

The major ions such as $\mathrm{Na}^{+}, \mathrm{Ca}^{2+}, \mathrm{Mg}^{2+}, \mathrm{Cl}^{-}$and $\mathrm{SO}_{4}{ }^{2-}$ were found within the range of 200 to $6000 \mathrm{mg} / \mathrm{L}, 50$ to $1100 \mathrm{mg} \mathrm{L}^{-1}, 25$ to $600 \mathrm{mg} \mathrm{L}^{-1}, 50$ to $4000 \mathrm{mg} \mathrm{L}^{-1}$ and 10 to $1000 \mathrm{mg} \mathrm{L}^{-1}$, respectively. $\mathrm{Ca}^{2+}$ concentrations in Karahayıt, Pamukkale, Emirfak1, Alaşehir and Sart were determined to be very high. The water type of these hot springs was mainly $\mathrm{Ca}-\mathrm{HCO}_{3}$. Çitgöl geothermal water exhibited $\mathrm{Na}-\mathrm{SO}_{4}$ water type. In general, hot springs of this study area were dominated by alkaline waters.
The alkaline spring waters show higher concentrations of Cr $\left(0.01-0.03 \mathrm{mg} \mathrm{L}^{-1}\right)$, As $(0.03-1.5 \mathrm{mg}$ $\left.\mathrm{L}^{-1}\right)$, B (0.01-4.05 mg L$\left.{ }^{-1}\right)$, Mn (0.01-0.23 mg L $\left.\mathrm{m}^{-1}\right)$, $\mathrm{S}\left(3.05-103 \mathrm{mg} \mathrm{L}^{-1}\right), \mathrm{Rb}\left(0.002-0.236 \mathrm{mg} \mathrm{L}^{-1}\right), \mathrm{Sr}$ (0.01-0.62 $\left.\mathrm{mg} \mathrm{L}^{-1}\right), \mathrm{Sb}\left(0.001-0.28 \mathrm{mg} \mathrm{L}^{-1}\right)$, and $\mathrm{Ba}$ (0.001-0.295 $\left.\mathrm{mg} \mathrm{L}^{-1}\right)$. The B concentrations were found to be very high in Salavatll $(3.79 \pm 0.005 \mathrm{mg}$ $\left.\mathrm{L}^{-1}\right)$, Sarayköy $\left(4.05 \pm 0.005 \mathrm{mg} \mathrm{L}^{-1}\right)$ and Kizıldere (3.78 $\left.\pm 0.005 \mathrm{mg} \mathrm{L}^{-1}\right)$ in comparison to other geothermal waters. As(III) was found to be the dominant species of geothermal waters in Alangülü $\left(82 \pm 0.002 \mu \mathrm{g} \mathrm{L}^{-1}\right)$, Salavatlı $(115 \pm 0.005 \mu \mathrm{g}$ $\left.\mathrm{L}^{-1}\right)$, Sarayköy $\left(430 \pm 0.006 \mu \mathrm{g} \mathrm{L}^{-1}\right)$ Buharkent (Inalt1) $\left(1002 \pm 0.02 \mu \mathrm{g} \mathrm{L}^{-1}\right)$, Buharkent (Babacik) $\left(43 \pm 0.007 \mu \mathrm{g} \mathrm{L}^{-1}\right)$, Kizldere $\left(889 \pm 0.03 \mu \mathrm{g} \mathrm{L}^{-1}\right)$ and Karahayit $\left(39 \pm 0.01 \mu \mathrm{g} \mathrm{L}^{-1}\right)$.

\subsection{Microbial diversity of geothermal water}

The bacterial isolates from Kula geothermal water were assigned to be closely related to $T$. subterraneus, a thermophilic, obligately chemolithoautotrophic, sulfur/thiosulfate-oxidizing bacterium that survive in the temperature range of $60-65^{\circ} \mathrm{C}$. This strain consumes thiosulfate during the growth and produces sulfate. The bacterial isolates from Buharkent, Babacık and Alangülü hot spring $\left(60^{\circ} \mathrm{C}\right)$ were assigned to be closely related to $M$. szegediense, a methanophilic bacterium that is able to metabolize methane as their only source of carbon and energy. The bacterial isolates from Sarayköy hot spring were assigned to be closely related to Sulfurovum lithotrophicum, a gram-negative, nonmotile, coccoid to oval-shaped bacterium that experiences optimum growth around $40^{\circ} \mathrm{C}$ in the $\mathrm{pH}$ range 5.0-9.0. This strain survives chemolithoautotrophically with elemental sulfur or thiosulfate as a sole electron donor and oxygen or nitrate as an electron acceptor. Connon et al. (2008) were reported that the As(III) oxidation occurred within bacterial mats along geochemical gradients of temperature and $\mathrm{pH}$. Due to As(III) oxidation in sulfate-chloride springs in the study area, $\mathrm{As}(\mathrm{V})$ is increased with the increase of $\mathrm{O}_{2}$ concentration while dissolved sulfide decreased at the same time. As a result, active deposition of $\mathrm{As}(\mathrm{V})-\mathrm{Fe}(\mathrm{III})$ oxides occurred in the hot spring. Reduced sulfur compounds or organic compounds can serve as an electron donor for $\mathrm{As}(\mathrm{V})$ reduction while $\mathrm{As}(\mathrm{III})$ may drive the reduction of stronger oxidants such as oxygen or nitrate (Oremland and Stolz, 2003).

\section{CONCLUSIONS}

The geothermal waters were observed to contain high concentrations of As, B and other toxic 
elements relative to WHO guidelines. Geothermal waters exhibited a diversity of water types such as $\mathrm{Na}-\mathrm{Cl}, \mathrm{Ca}-\mathrm{HCO}_{3}$ and $\mathrm{Na}-\mathrm{SO}_{4}$. As(III) predominated in comparison to other species. The geothermal waters were rich in bacterial diversity such as thermophilic and mesophilic, sulfur/thiosulfateoxidizing bacterium, methanophilic bacterium and thermophilic, aerobic endospore forming bacterium. Chemolithoautotrophically and microbiologically, the active deposition of $\mathrm{As}(\mathrm{V})-\mathrm{Fe}(\mathrm{III})-$ oxides occurred in these hot springs. Microbial activity plays an important role in As transformation at the eruption point of geothermal water, as $\mathrm{As}(\mathrm{III})$ is transformed to $\mathrm{As}(\mathrm{V})$ by detoxification pathways of microorganisms.

\section{REFERENCES}

Baba, A. \& Ármannsson, H. 2006. Environmental Impact of the utilization of a geothermal area in Turkey. Energy Source. 1: 267-278.

Connon, S.A., Koski, A.K., Neal, A.L., Wood, S.A. \& Magnuson, T.S. 2008. Ecophysiology and geochemistry of microbial arsenic oxidation within a high arsenic, circum neutral hot spring systemof the Alvord Desert. FEMS Microbiol. Ecol 64: 117-128.

Oremland, R.S. \& Stolz, J.F. 2003. The ecology of arsenic. Science 300: 939-944. 